\title{
Comparative evaluation of different fungicides and bio-agents for management of spot blotch of barley caused by Bipolaris sorokiniana (Sace. Ex Sorok)
}

\author{
Javed Bahar Khan, Sugam Katiyar, Charul Kanchan, Jitendra Kumar and Pravir Kumar Gupta* \\ Section of Rabi Cereals, C.S.Azad. Univ. of Agri. \& Tech. Kanpur (UP)-208002
}

Article history: Received: 11 Dec., 2020 Revised: 13 June, $2021 \quad$ Accepted: 15 Aug., 2021

Citation: Khan JB, S Katiyar, C Kanchan, J Kumar and PK Gupta. 2021. Comparative evaluation of different fungicides and bio-agents for management of spot blotch of Barley Caused by Bipolaris sorokiniana (Sace. Ex Sorok). Journal of Cereal Research 13(2): 211-214. http://doi.org/10.25174/2582-2675/2021/114191

\author{
*Corresponding author: pkguptacsau@rediffmail.com \\ (c) Society for Advancement of Wheat and Barley Research
}

Keywords: Difenconazole, Hordeum vulgare, Per cent growth inhibition, Psudomonas fluorescens, Systemic fungicide, Trichoderm harzianum.

Barley (Hordeum vulgare L) is one of the first domesticated cereal crop after maize, rice and wheat, which contributes $5.5-6.0 \%$ of the global cereals and $11.5-12$ per cent of the coarse cereals production (Pal et al. 2012, Kumar et al. 2013b, Kumar et al. 2014). Barley is used as food crop in many countries of Africa, Middle East, South America and Asia. During 2019-20 in India, the area under the crop was 0.62 million hectare, productivity $25.73 \mathrm{q} /$ ha with a production of 1.59 million metric tonns (Anonnymous 2019-20). In India, barley is an important coarse cereal crop being grown in Rabi (winter) season in Northern plains. Barley occupies area in 10 states viz. Himanchal Pradesh, Jammu \& Kashmir, Bihar, Maharashtra, West Bengal, Punjab, Haryana, Madhya Pradesh, Uttar Pradesh and Rajasthan (Randhir Singh et al. 2014). Malt is the second largest use of barley and among cereals, barley is preferred for Kernel and its enzymatic activity ( $\alpha$ and $\beta$ amylase mainly) (Shaveta et al. 2019). The utilization of barley for malting and brewing industry has increased recently with the increase in consumption of beer, health drinks and other malt based products in India (Randhir Singh et al. 2014). Currently it has received attention of research workers to boost its production through the adoption of new technology and high yielding varieties.
Like other cereals, barley is also exposed to various diseases which are ultimately responsible for significant yield reduction and poor grain quality. Barley is exposed to several biotic stresses, however, some of these are rust, spot blotch, net blotch, powdery mildew, loose smut and covered smut (Gangwar et al. 2018). Among these, spot blotch caused by Bipolaris sorokiniana is an important fungal disease causing severe losses up to 25-30 per cent reduction in grain yield and also reduces the grain quality (Randhir Singh et al. 2014). Keeping in view, the importance of disease, especially with reference to the state of Uttar Pradesh, it is better to have management well in advance. The management of disease can be done through cultural practices and use of resistant genotype, but there is need for efficient management of disease with eco-friendly means.

In vitro, six systemic fungicides against Bipolaris sorokininia viz; Propiconazole, Tebuconazole, Azoxystrobin, Difenconazole, Azoxystrobin + Difenconazole and Mancozeb and five bio-agents viz. T.viride-1, T. viride-2, T. harzianum-1, T. harzianum-2 and Pseudomonas fluorescens were tested against the pathogen to find out their relative efficacy in inhibiting the growth of fungus in culture in four dilutions (25 ppm, 50 ppm, 100 ppm and 200 ppm) using 
poisoned food technique proposed by Nene and Thapliyal, (1993). The desired concentrations were obtained by adding appropriate amount of stock solution of fungicides to potato dextrose agar (PDA) medium in petri dishes. PDA without fungicides served as control. Each plate was inoculated with a $5 \mathrm{~mm}$ mycelial disc of the pathogen i.e. fungus taken from 7-days old culture. The inoculated plates were incubated at $25 \pm 1^{\circ} \mathrm{C}$ till the fungus covered the whole plate in control. For antagonistic activities of five bio-control agents, dual culture technique was used (Rahman 2009 ). Five mm diameter disc of actively growing pathogen (B. sorokiniana) taken from the margin of 10-days old culture was placed at one end of petri dish containing solidified PDA medium. The inoculation of mycelia disc $(5 \mathrm{~mm})$ of antagonist at opposite end of petri dish was done 3-days after the placement of pathogen in order to adjust the slow growth rate of pathogen. The disc of pathogen and antagonist were placed at equal distance from the periphery of petri dish. In case of bacterial antagonist, culture disc ( $5 \mathrm{~mm}$ diameter) of the pathogen was placed at one end of the petri dishes containing PDA medium and after three days the bacterial antagonist was streaked on opposite side of the growing pathogen colony. The plate containing PDA medium inoculated with pathogen only, served as control. The both experiments were conducted under Complete Randomized Design with four replications for each treatment. The inoculated plates were incubated at $25 \pm 1^{\circ} \mathrm{C}$.

The redial growth of colony was recorded and per cent inhibition of each treatment was calculated by using formula given by Vincent (1927).

$\begin{aligned} & \text { Growth } \\ & \text { inhibition }(\mathrm{I})\end{aligned}=\frac{\text { Radial growth in control }(\mathrm{C}) \text { - radial growth in treatment }(\mathrm{T})}{\text { Radial growth in control }(\mathrm{C})} \times 100$

Where,

$\mathrm{I}=$ Per cent growth inhibition

$\mathrm{C}=$ Growth of pathogen $(\mathrm{mm})$ in control

$\mathrm{T}=$ Growth of pathogen $(\mathrm{mm})$ in treatment

All the six fungicides significantly inhibited the mycelial growth of B. sorokiniana at all doses (25, 50, 100 and 200 ppm). There was a significant decrease in the respective mycelial growth and accordingly more inhibition was observed at higher concentration (200 ppm) than lower concentrations. A significant interaction between pathogen and concentration of fungicides was observed (Table-1). Among the fungicides viz. Propiconazole,
Azoxystrobin, Azoxystrobin + Difenconazole and Tebuconazole were most effective. Propiconazole showed 91.51, 97.67, 100.00 and 100.00 per cent inhibition, while Tebuconazole exhibited 87.20, 95.11, 100.00 and 100.00 per cent mycelial inhibition at 25, 50, 100 and 200 ppm concentration respectively and followed by Azoxystrobin exhibiting 87.20, 94.18, 100 and 100 per cent mycelial inhibition at 25, 50, 100 and 200 ppm, respectively. Next to these fungicidal treatment against the B. sorokininia was Azoxystrobin + Difenconzole which showed inhibition of 87.20, 94.18, 95.34 and 100 per cent followed by Difenconazole recording mycelial growth inhibition of 85.34, 87.20, 90.69 and 96.27 per cent. Mancozeb was least effective fungicide exhibiting 27.90, 31.39, 48.83 and 89.18 per cent inhibition respectively. Fungicides Propiconazole, Tebuconazole, Azoxystrobin and Azoxystrobin + Difenconazole were found most effective exhibiting 100 per cent inhibition at 200ppm followed by Difenconazole (96.27) and Mancozeb (89.18) per cent. The similar findings were reported by Mahapatra and Das, 2013. Padha (2008) reported that Propiconazole and Tebuconazole completely inhibited mycelial growth of B. sorokiniania at $25 \mathrm{ppm}$ and higher concentration. No growth of Drechslera sorokiniana had been reported when fungicide Mancozeb was used (Chattannavar et al. 1985). Hasan et.al. (2012) reported that systemic fungicides completely inhibited the growth of pathogen at lower concentration under laboratory condition. Bio-agents viz; T. viridi-1, T. viridi-2, T. harzianum-2, T. harzianum-1 and Pseudomonas fluorescens were evaluated against $B$. sorokiniana and showed highly significant inhibiting effect on mycelial growth. Data presented in Table-2 showed that $T$. harzianum-1 was most effective exhibiting 77.90 per cent mycelial inhibition of the pathogen followed by T. harzanium-2 (74.80 per cent) and T. viride- 1 (74.41 per cent). These three were at par with each other. Bacterial bio-agent $P$. fluorescens was least effective reducing 47.22 per cent mycelia growth of pathogen. Hasan et. al. (2008) found that species of Trichoderma inhibited the mycelia growth of $F$. monilifarmae in the range of 32.50 to 45.00 per cent. Hasan (2013) reported that T.harzanium isolates RVT103 effectively reduced radial growth of $B$. sorokiniana (45.45 \%). According to Harman (2006), Trichoderma spp. sensed the presence of target fungi and appeared to grow towards them. 
Table 1: In vitro evaluation of different fungicides against B. sorokiniana.

\begin{tabular}{|c|c|c|c|c|c|c|c|c|}
\hline \multirow{3}{*}{ Treatment } & \multicolumn{8}{|c|}{ Mean radial growth $(\mathrm{mm})$ at different concentration (ppm) } \\
\hline & \multicolumn{2}{|c|}{25} & \multicolumn{2}{|r|}{50} & \multicolumn{2}{|c|}{100} & \multicolumn{2}{|c|}{200} \\
\hline & $\begin{array}{l}\text { Growth } \\
(\mathrm{mm})\end{array}$ & $\begin{array}{c}\text { Inhibition } \\
(\%)\end{array}$ & $\begin{array}{c}\text { Growth } \\
(\mathrm{mm})\end{array}$ & $\begin{array}{c}\text { Inhibition } \\
(\%)\end{array}$ & $\begin{array}{c}\text { Growth } \\
(\mathrm{mm})\end{array}$ & $\begin{array}{c}\text { Inhibition } \\
(\%)\end{array}$ & $\begin{array}{c}\text { Growth } \\
(\mathbf{m m})\end{array}$ & $\begin{array}{c}\text { Inhibition } \\
(\%)\end{array}$ \\
\hline Propiconazole & $7.30^{* *}$ & 91.51 & $2.00^{* *}$ & 97.67 & $0.00 * *$ & 100.00 & $0.00^{* *}$ & 100.00 \\
\hline Tebuconazole & $11.00^{* *}$ & 87.20 & $4.20^{* *}$ & 95.11 & $0.00^{* *}$ & 100.00 & $0.00^{* *}$ & 100.00 \\
\hline Azoxystrobin & $51.60^{* *}$ & 40.00 & $12.00^{* *}$ & 86.04 & $4.80^{* *}$ & 94.41 & $0.00^{* *}$ & 100.00 \\
\hline Difenconazole & $12.60^{* *}$ & 85.34 & $11.00^{* *}$ & 87.20 & $8.00^{* *}$ & 90.69 & $3.20^{* *}$ & 96.27 \\
\hline $\begin{array}{l}\text { Azoxystrobin + } \\
\text { Difenconazole }\end{array}$ & $11.00^{* *}$ & 87.20 & $5.00 * *$ & 94.18 & $4.00^{* *}$ & 95.34 & $0.00^{* *}$ & 100.00 \\
\hline Mancozeb & $62.00^{* *}$ & 27.90 & $59.00^{* *}$ & 31.39 & $44.00^{* *}$ & 48.83 & $9.30^{* *}$ & 89.18 \\
\hline Control & 86.00 & - & 86.00 & - & 86.00 & - & 86.00 & - \\
\hline $\operatorname{SE}(d)$ & 1.32 & - & 1.31 & - & 0.70 & - & 0.57 & - \\
\hline CV (\%) & 4.68 & - & 6.30 & - & 4.33 & - & 4.96 & - \\
\hline S.E.m \pm & 0.93 & - & 0.93 & - & 0.50 & - & 0.40 & - \\
\hline CD (1\%) & 2.83 & - & 2.82 & - & 1.51 & - & 1.22 & - \\
\hline
\end{tabular}

** Significant at $1 \%$ level

Table 2: Effect of antagonists on the growth of B. sorokiniana by dual culture method:

\begin{tabular}{ccc}
\hline Antagonist & Mycelial growth $(\mathrm{mm})$ & Growth inhibition $(\%)$ \\
\hline Trichoderma viride-1 & $22.00^{* *}$ & 74.41 \\
T. viride-2 & $26.33^{* *}$ & 69.37 \\
T. harzianum-1 & $19.00^{* *}$ & 77.90 \\
T. harzianum-2 & $21.66^{* *}$ & 74.80 \\
Pseudomonas flourescens & $45.33^{* *}$ & 47.22 \\
Control & 86.00 & - \\
SE $(\mathrm{d})$ & 1.53 & - \\
CV $(\%)$ & 5.13 & - \\
S.E.m+ & 1.08 & - \\
CD $(1 \%)$ & 3.33 & \\
\hline
\end{tabular}

** Significant at $1 \%$ level

\section{Conclusion}

Among the fungicides Propiconazole, Tebuconazole, Azoxystrobin and Azxoxystrobin + Difenconazole completely inhibited the mycelia growth of pathogen at 200 ppm concentration under in-vitro condition. Among bio control agents, T. harzianum-1 (77.90 per cent) was found most effective antagonist against pathogen followed by $T$. harzianum-2 (74.80per cent) and T. viride-1 (74.41per cent).

\section{Compliance with ethical standards}

NA

\section{Conflict of Interest}

Authors declare that they have no conflict of interest

\section{Authors' contribution}

The compliance of referee comments has been made. The manuscript Comparative Evaluation of Different Fungicides and Bio-agents for Management of Spot Blotch of Barley Caused by Bipolaris sorokiniana (Sace. Ex Sorok) is a part of M. Sc. Ag. Thesis of Mr. Sugam Katiyar submitted in C S A Univ. of Agri. and Tech., Kanpur. 


\section{References}

1. Agrios GN. 2005. Plant Pathology. $5^{\text {th }}$ Ed. Academic Press, San Diego, USA, 922p.

2. Anonymous. 2016. Progress report of All India Coordinated Wheat and barley improvement Project 2015-16, Barley Network. Indian Institute of Wheat and barley Research, Karnal, India, 309p.

3. Chattannavar SN, S Kulkarni, RK Hegde and G Jatinder. 1985 Status of Alternaria leaf blight of wheat in Karnataka. Plant Pathology News Letter, 3: 17-19.

4. Gangwar OP, SC Bharadwaj, GP Singh, P Prasad and S Kumar. 2018. Barley diseases and management: An Indian Perspective. Wheat and Barley Research, 10(3): 138-150.

5. Harman GE. 2006. Overview of mechanism and uses of Trichoderma spp. Phytopathology, 96:190-194.

6. Hasan A, F Wanlker and H Buchenauer. 2008. Trichorderma harzianum and its metabolic 6-pentylalphaphyrone suffressfusanic acid produced by Fusanium maniliformae. Journal of Phytopathology, 156: 79-87.

7. Hasan MM. 2013. Biological Control of wheat diseases caused by Bipolaris sorokiniana, Fusarium graminearum and Aspergillus flavuswith antagonist's of Trichoderma spp. Persian Gulf Crop Protection, 2: 1-9.

8. Hasan MM, F Ahmad, MR Islam and KFI Murad. 2012. In vitro effect of botanical extract and fungicides against Bipolaris sorokiniana, caused agent of leaf blotch of barley. Journal of Agroforestry and Environment, 6: $82-87$.

9. Kumar V, R Kumar, RPS Verma, A Verma and J Sharma. 2013. Recent trends in breeder seed production of barley (Hordeum vulgare L.). Indian Journal of Agricultural Sciences, 83: 576-578.
10. Kumar V, A Rathore, AS Kharub, D Kumar and I Sharma. 2014. GGE biplot analysis of multilocational yield trials and identified of representative environments for barley (Hordeum vulgare L.) in India. Research on Crop, 15: 871-875.

11. Mahapatra S and S Das. 2013. Efficacy of ddddifferent fungicides against spot bloch of wheat in tarai region of West Bengal. Journal of Wheat Research, 5(2): 18-20.

12. Nene, YL and PN Thapaliyal. 1993. Evaluation of fungicides. In: Fungicides in plant diseases control ( $3^{\text {rd }}$ Ed.). Oxford and IBH Publishing Company, New Delhi, pp-33.

13. Padha V. 2008. Investigation of spot blotch of wheat (Biplorais sorokiniana). M.Sc. Ag. Thesis, Division of Plant Pathology, SKUAST, Jammu, 46p.

14. Pal D, S Kumar and RPS Verma. 2012. Pusa Losar (BHS380)- The first dual purpose barley variety for northern hills of India. Indian Journal of Agricultural Sciences, 82: 164-165.

15. Rahman. 2009. Screening of Trichoderma isolates as a biological control agent Ceratocystis parodoxa causing pine apple disease of sugarcane. Mycology, Dec. 2009, 37(4): 277-285.

16. Shaveta, H Kaur and S Kaur. 2019. Huskless barley: A new Era of research for food purpose. Journal of Cereal Research, 11(2): 114-124.

17. Singh R, A Kumar, AS Kharab, V Kumar, R Shelvakumar, Ramesh Chandra and Indu Sharma. 2014. Barley cultivation in India (Pocket guide), Directorate of wheat Research, Karnal. Extension Bulletin : 53, 18p. 